\title{
Left Cardiac Ventricular Pacing Malfunction
}

National Cancer Institute

\section{Source}

National Cancer Institute. Left Cardiac Ventricular Pacing Malfunction. NCI Thesaurus. Code $C 99973$.

The cardiac rhythm device malfunction affected the left ventricular (LV) pacing. (ACC) 